\title{
Increased feeding frequency increased milk fat yield and may reduce the severity of subacute ruminal acidosis in higher-risk cows
}

\author{
K. Macmillan, X. Gao, and M. Oba ${ }^{1}$ \\ Department of Agricultural, Food and Nutritional Science, University of Alberta, Edmonton, AB, T6G 2P5, Canada
}

\begin{abstract}
The objectives of this study were to determine whether feeding behavior is different between cows at higher or lower risk for subacute ruminal acidosis (SARA) and whether increasing feeding frequency could be used to reduce the severity of SARA in higher-risk cows. In preliminary studies, 16 ruminally cannulated lactating cows were fed high-grain diets once per day to increase the risk of SARA. After a 17-d diet adaptation, ruminal $\mathrm{pH}$ was measured every $30 \mathrm{~s}$ over $24 \mathrm{~h}$. Cows were classified as higher-risk $(\mathrm{n}=7)$ or lower-risk $(\mathrm{n}=9)$ for SARA based on an acidosis index (area of $\mathrm{pH}<5.8 /$ dry matter intake). Feeding behavior was recorded every 5 min over the same $24 \mathrm{~h}$. The 24 -h observation period was analyzed in 3 periods of $8 \mathrm{~h}$ after feeding. Although there was no significant difference in overall dry matter intake, higher-risk cows spent more time eating in the first 8-h period after feeding than lower-risk cows (186 vs. $153 \mathrm{~min}$ ) and less time eating in the third 8-h period (19 vs. $43 \mathrm{~min}$ ). In the primary experiment, 8 ruminally cannulated lactating cows were fed a high-grain diet once per day $(1 \times ; 0800 \mathrm{~h})$ or 3 times per day $(3 \times ; 0800$, 1500 , and $2000 \mathrm{~h}$ ) in a crossover design with 21 -d periods (16 d of treatment adaptation and $5 \mathrm{~d}$ of data collection). Rumen $\mathrm{pH}$ and feeding behavior were measured over $72 \mathrm{~h}$. Behavior data were summarized separately for the 3 periods (0800 to 1500,1500 to 2200 , and 2200 to $0800 \mathrm{~h}$ ). Four cows were categorized as higher-risk and 4 as lower-risk, based on their acidosis index. The $3 \times$ feeding reduced eating time between 0800 and 1500 $\mathrm{h}$ (99 vs. $145 \mathrm{~min}$ ) and increased eating time between 2200 and $0800 \mathrm{~h}$ (76 vs. $43 \mathrm{~min}$ ) for all cows, regardless of category, compared with $1 \times$ feeding. For higher-risk cows, $3 \times$ feeding reduced the area below $\mathrm{pH} 5.8$ (51 vs. $98 \mathrm{pH} \times \mathrm{min} / \mathrm{d}$ ), but it did not affect rumen $\mathrm{pH}$ for the lower-risk cows. Milk yield was not different between groups, but $3 \times$ feeding increased milk fat yield (1.22 vs. $1.08 \mathrm{~kg} / \mathrm{d})$ for all cows, regardless of category, compared to $1 \times$ feeding. Our results suggest that cows
\end{abstract}

Received April 19, 2016

Accepted October 14, 2016.

${ }^{1}$ Corresponding author: moba@ualberta.ca at higher risk for SARA eat less evenly throughout the day; increasing feeding frequency may reduce the severity of SARA in higher-risk cows and may also increase milk fat yield.

Key words: subacute ruminal acidosis, feeding frequency, feeding behavior, milk fat

\section{INTRODUCTION}

Subacute ruminal acidosis is a metabolic disorder found mainly in high-producing dairy cows that are fed highly fermentable diets. A prolonged rumen $\mathrm{pH}$ below 5.8 can lead to problems in animal health (such as laminitis and liver abscess) and production losses from milk fat depression and reduced DMI (Nocek, 1997). Previous research has established that individual rumen $\mathrm{pH}$ response to the same high-grain diet in beef steers (Schlau et al., 2012) and dairy cows (Penner et al., 2007) varies widely, but the causes of this variation have not been clearly identified. In recent studies, cows were categorized as tolerant of or susceptible to a high-grain diet using an acidosis index, which is the severity of SARA normalized for intake (area below pH 5.8/DMI; Penner et al., 2009), and efforts were made to characterize animals that were tolerant of a high-grain diet. Schlau et al. (2012) observed decreased VFA concentrations in tolerant animals, possibly due to decreased VFA production or increased absorption. Gao and Oba (2014) reported that tolerant animals showed less sorting against long particles. However, the distribution of feeding behavior among animals with different tolerance to a high-grain diet has not yet been evaluated. Eating larger amounts of feed over a short period can lead to a rapid decrease in rumen $\mathrm{pH}$ (González et al., 2012), so it is possible that cows more prone to SARA exhibit different feeding behaviors or eating patterns throughout the day.

Previous studies have found that increasing feeding frequency reduced diurnal variation in rumen $\mathrm{pH}$ (French and Kennelly, 1990; Shabi et al., 1999). The delivery of fresh feed stimulated eating in cows (DeVries and von Keyserlingk, 2005) and feeding more often led to more frequent peaks in eating activity, correspond- 
ing to feeding times (Mäntysaari et al., 2006). DeVries et al. (2005) also found that feeding 4 times per day, instead of once or twice, reduced the time spent eating in the 90 min after each feeding. Therefore, increasing the frequency of feeding may encourage distribution of eating throughout the day, reducing large intake after feed delivery and contributing to a more stable $\mathrm{pH}$. Although the effects of feeding frequency have been extensively studied, findings for its effect on rumen $\mathrm{pH}$ have not been consistent (French and Kennelly, 1990; Robinson and McQueen, 1994; Shabi et al., 1999).

The objective of the preliminary studies was to determine whether cows that differed in their risk for SARA also differed in their distribution of feeding behavior throughout the day. We hypothesized that higher-risk cows fed once per day would eat for a longer period of time soon after feeding and would reduce eating time later in the day. The objective of the primary experiment was to determine the effects of increased feeding frequency on feeding behavior and rumen $\mathrm{pH}$ in lactating dairy cows with different risk levels for developing SARA. We hypothesized that frequent feeding would increase the distribution of eating throughout the day and reduce the severity of SARA in higher-risk cows.

\section{MATERIALS AND METHODS}

All experimental procedures used in this study were approved by the University of Alberta Animal Care Committee and conducted according to the guidelines of the Canadian Council of Animal Care (CCAC, 2009). All cows were housed individually in a tiestall barn bedded with wood shavings and with free access to water. Cows were milked twice per day at 0400 and $1500 \mathrm{~h}$. Cows were fed for 5 to $10 \%$ daily orts.

\section{Preliminary Studies}

Study 1 was conducted in 2012 (Gao and Oba, 2014) with 10 ruminally cannulated lactating Holstein cows $(\mathrm{DIM}=277 \pm 37 ; \mathrm{BW}=600 \pm 77 \mathrm{~kg})$, and study 2 was conducted in 2014 (Gao and Oba, 2015) with 9 ruminally cannulated lactating Holstein cows (DIM = $247 \pm 19 ; \mathrm{BW}=686 \pm 42 \mathrm{~kg})$. In both studies, cows were fed high-grain diets once per day to induce SARA (Table 1), at $0800 \mathrm{~h}$ for study 1 and $0900 \mathrm{~h}$ for study 2. For both studies, cows were fed ad libitum for $21 \mathrm{~d}$ with $17 \mathrm{~d}$ of diet adaptation and $4 \mathrm{~d}$ of sample and data collection. Although the preliminary studies focused solely on the collection of rumen $\mathrm{pH}$ and behavior data, Gao and Oba (2014) also measured VFA concentrations from rumen fluid samples; sorting behavior; blood metabolites; and milk yield and components. For cows used in both studies $(\mathrm{n}=3)$, data from study 2 were used, leaving a total of 16 cows for statistical analysis. Of these, 3 were primiparous and 13 were multiparous.

In both studies, rumen fluid $\mathrm{pH}$ was measured continuously in the ventral sac every $30 \mathrm{~s}$ for $24 \mathrm{~h}$ on d 18 using the $\mathrm{pH}$ measurement system evaluated by Penner et al. (2006). This system was used to determine mean, minimum, and maximum $\mathrm{pH}$, as well as duration and area below $\mathrm{pH}$ of 5.8 for each cow. The data were then used to determine an acidosis index (area below $\mathrm{pH}$ 5.8/DMI; Penner et al., 2009), which indicated the severity of SARA normalized for intake. Cows below the acidosis index threshold of 1.0 were categorized as lower risk, and cows above the threshold were categorized as higher risk.

For both studies, we recorded feeding behavior over $24 \mathrm{~h}$ on d 18, coinciding with rumen $\mathrm{pH}$ recording. All behavior observers were trained to standardize behavior definitions and recordings. Cows were observed for eating and ruminating every $5 \mathrm{~min}$, and the behavior performed at that time was recorded and assumed to last for the full $5 \mathrm{~min}$ (Beauchemin et al., 2003). We summarized feeding behavior for 3 time periods of $8 \mathrm{~h}$ relative to feeding, to account for the different feeding times in the 2 experiments (e.g., if the cow was fed at $0800 \mathrm{~h}$, time period 1 was 0800 to $1600 \mathrm{~h}$, time period 2 was 1600 to $2400 \mathrm{~h}$, and time period 3 was 2400 to $0800 \mathrm{~h}$ ). This approach allowed us to determine when the cows spent more time eating, relative to feed delivery. The minimum interval between bouts of eating was $\geq 10 \mathrm{~min}$, or else cows were assumed to be still eating, as described by Dado and Allen (1993).

We evaluated all response variables using the Fit Model procedure in JMP (version 11, SAS Institute Inc., Cary, NC). The model included the fixed effects of experiment (1a vs. 1b), category (higher risk vs. lower risk of SARA), and the interaction of experiment by category. Because the interaction between experiment and category was not significant $(P>0.10)$, the interaction term was removed from the statistical model. We declared significance at $P \leq 0.05$ and tendency at $0.05<P \leq 0.10$

\section{Primary Experiment}

Eight ruminally cannulated lactating Holstein cows were used in this crossover design study with periods of $21 \mathrm{~d}$ (Table 2). Treatments were feeding frequency: 4 cows were fed once per day $(\mathbf{1} \times)$ at $0800 \mathrm{~h}$, and the other 4 cows were fed 3 times per day $(\mathbf{3} \times)$ at 0800, 1500, and $2200 \mathrm{~h}$. We chose 3 feedings because a previous study had found increased treatment effects on feeding behavior when feeding frequency was more than twice per day (DeVries et al., 2005). A TMR was mixed once before the $0800 \mathrm{~h}$ feeding for all cows; the 
Table 1. Ingredient and chemical composition of diets for preliminary studies 1 and 2 , and the primary experiment

\begin{tabular}{lccc}
\hline Item & Study $1^{1}$ & Study $2^{2}$ & Primary experiment \\
\hline Ingredient, \% of DM & & & \\
Barley silage & 30.0 & 30.0 & 36.5 \\
Barley grain, dry rolled & 25.0 & 25.5 & 24.1 \\
Corn grain, ground & 20.0 & 18.9 & 14.0 \\
Canola meal & 7.4 & 14.5 & 3.6 \\
Corn gluten meal & 5.3 & 4.7 & - \\
Alfalfa hay & 5.0 & - & 0.9 \\
Beet pulp & 4.0 & 0.9 & $2.3^{5}$ \\
Vegetable oil & 1.0 & $2.6^{4}$ & 56.2 \\
Mineral and vitamin mix & $2.4^{3}$ & & 18.5 \\
Nutrient composition, \% of DM & & 54.6 & 29.4 \\
DM & 60.8 & 16.9 & 31.6 \\
CP & 15.9 & 26.8 & 4.0 \\
NDF & 25.6 & 31.8 & 42.7 \\
Starch & 31.1 & 4.1 & 17.9 \\
Ether extract & 4.0 & 47.5 & \\
NFC & 49.8 & 13.9 & \\
Forage NDF & 14.3 & & \\
\hline
\end{tabular}

${ }^{1}$ Gao and Oba, 2014.

${ }^{2} \mathrm{Gao}$ and Oba, 2015.

${ }^{3}$ Contained (per kilogram): $15.7 \% \mathrm{Ca}, 3.32 \% \mathrm{P}, 14.1 \% \mathrm{Na}, 21.8 \% \mathrm{Cl}, 5.70 \% \mathrm{Mg}, 0.23 \% \mathrm{~S}, 0.06 \% \mathrm{~K}, 2,867.4 \mathrm{mg}$ of Fe, $468.7 \mathrm{mg}$ of $\mathrm{Cu}, 902.8 \mathrm{mg}$ of $\mathrm{Mn}, 11.2 \mathrm{mg}$ of Co, $718.0 \mathrm{mg}$ of Zn, $7.08 \mathrm{mg}$ of Se, $21.0 \mathrm{mg}$ of I, $442.8 \mathrm{kIU}$ of vitamin A, $45.0 \mathrm{kIU}$ of vitamin D, 1,449.9 kIU of vitamin $\mathrm{E}$.

${ }^{4}$ Contained (per kilogram): $15.35 \% \mathrm{Ca}, 2.83 \% \mathrm{P}, 12.44 \% \mathrm{Na}, 24.99 \% \mathrm{Cl}, 5.53 \% \mathrm{Mg}, 0.28 \% \mathrm{~S}, 6.43 \% \mathrm{~K}, 3,274.31$ $\mathrm{mg}$ of $\mathrm{Fe}, 617.15 \mathrm{mg}$ of $\mathrm{Cu}, 1,160.00 \mathrm{mg}$ of $\mathrm{Mn}, 13.92 \mathrm{mg}$ of Co, $937.69 \mathrm{mg}$ of Zn, $9.23 \mathrm{mg}$ of Se, $30.25 \mathrm{mg}$ of I, $473.1 \mathrm{kIU}$ of vitamin A, 48.0 kIU of vitamin D, 1,547.7 IU of vitamin E.

${ }^{5}$ Contained (per kilogram): $19.1 \% \mathrm{Ca}, 2.99 \% \mathrm{P}, 19.5 \% \mathrm{Cl}, 4.92 \% \mathrm{Mg}, 0.06 \% \mathrm{~K}, 12.7 \% \mathrm{Na}, 0.28 \% \mathrm{~S}, 3,667 \mathrm{mg}$ of Fe, 1,147 mg of Cu, 2,115 mg of Mn, $24.7 \mathrm{mg}$ of Co, 1,432 mg of Zn, $54.1 \mathrm{mg}$ of I, $17.2 \mathrm{mg}$ of Se, $536 \mathrm{kIU}$ of vitamin A, $54.9 \mathrm{kIU}$ of vitamin D, 1,734 IU of vitamin $\mathrm{E}$.

TMR for the $3 \times$ cows was separated into thirds and vacuum-sealed to minimize spoilage and heating. Cows were weighed after the morning milking on 2 consecutive days immediately before the start of the study. Four cows in early lactation $(\mathrm{DIM}=50 \pm 20)$ and 4 cows in late lactation (DIM $=381 \pm 46)$ were used; 2 early- and 2 late-lactation cows were assigned to each treatment sequence, $1 \times$ to $3 \times$ or $3 \times$ to $1 \times$. All cows were fed the same diet containing $36.5 \%$ forage, $17.9 \%$ forage NDF, and $31.6 \%$ starch to induce SARA (Table $1)$. The DM concentration of the barley silage was determined twice per week, and the diet formulation was adjusted if necessary. Each period of the study included $16 \mathrm{~d}$ of treatment adaptation and $5 \mathrm{~d}$ of sample and data collection. Samples of TMR and orts for each cow were collected from d 17 to 19 , and the orts were composited to yield 1 sample per cow.

We measured rumen $\mathrm{pH}$ as described for the preliminary studies, but over $72 \mathrm{~h}$ (d 17 to 19), so we averaged $\mathrm{pH}$ variables (minimum, mean, maximum, and area and duration below 5.8) across days to obtain 1 value per cow per period. We normalized the area below $\mathrm{pH}$ 5.8 for DMI by dividing the area below 5.8 for each cow by its individual intake, to determine the acidosis index. The acidosis index calculated for $1 \times$ treatment was used to categorize cows as higher-risk or lower-risk for SARA, because this was our baseline measurement.

We evaluated feeding behavior as described for the preliminary studies, except that we recorded it over 72 h (d 17 to 19 ) to coincide with the $\mathrm{pH}$ measurement period. Feeding behavior was recorded as (1) eating, (2) ruminating and standing, (3) ruminating and lying, (4) no activity and standing, or (5) no activity and lying. Behavior was analyzed separately for 3 different time periods, based on the $3 \times$ feeding schedule. Time periods 1,2 , and 3 were 0800 to $1500 \mathrm{~h}, 1500$ to 2200 h, and 2200 to $0800 \mathrm{~h}$, respectively. We wanted each time period to start with a feeding for the $3 \times$ cows to better determine the effect of feed delivery on their

Table 2. Characteristics of higher risk and lower risk cows in the primary experiment ${ }^{1}$

\begin{tabular}{lcccc}
\hline Variable & $\begin{array}{c}\text { Higher } \\
\text { risk }\end{array}$ & $\begin{array}{c}\text { Lower } \\
\text { risk }\end{array}$ & SE & $P$-value \\
\hline Parity & 3.75 & 3.00 & 0.60 & 0.41 \\
DIM & 216 & 214 & 97.6 & 0.99 \\
Weight & 718 & 687 & 34.2 & 0.54 \\
BCS & 3.13 & 3.00 & 0.14 & 0.54 \\
\hline
\end{tabular}

${ }^{1}$ Cows were categorized as higher risk or lower risk for developing SARA using a threshold of 1.0 in acidosis index (area below pH 5.8/ DMI). 
feeding behavior. The minimum interval between bouts of eating was $10 \mathrm{~min}$, and between bouts of ruminating and lying was $5 \mathrm{~min}$. We determined the particle size distribution of the TMR and orts samples using a Penn State Particle Separator with 3 sieves (aperture sizes of 19.0, 8.0, and $1.18 \mathrm{~mm}$ ). The particle size distribution for the TMR was $6.2 \%$ on the top screen, $38.9 \%$ on the middle screen, $38.5 \%$ on the bottom screen, and $16.5 \%$ in the pan. We calculated the sorting index as the ratio of actual intake to predicted intake of particles retained on each sieve of the separator. A sorting index above 100 indicates sorting for particles and an index below 100 indicates sorting against particles (Leonardi and Armentano, 2003).

We collected milk samples at both a.m. and p.m. milkings on d 17 to 19. Samples were analyzed for fat, $\mathrm{CP}$, lactose, and MUN by infrared spectroscopy (AOAC International, 2002; method 972.16; MilkoScan 605, Foss North America, Brampton, ON, Canada) at the Alberta Central Milk Testing Laboratory (Edmonton, AB, Canada).

On d 20, cows were fitted with a jugular catheter to facilitate blood sample collection on d 21. Samples were collected every $3 \mathrm{~h}$ over $24 \mathrm{~h}$ starting at $0700 \mathrm{~h}$, into tubes containing heparin (Fisher Scientific Company, Nepean, ON, Canada). Samples were centrifuged at $3,000 \times g$ at $4^{\circ} \mathrm{C}$ for 20 min immediately after collection; plasma was harvested and stored at $-20^{\circ} \mathrm{C}$ until further analysis. We analyzed plasma samples for glucose concentrations using a glucose oxidase and peroxidase enzyme (Sigma, St. Louis, MO) and a dianisidine dihydrochloride (Sigma) procedure. We determined absorbance using a plate reader (SpectraMax 190, Molecular Devices Corp., Sunnyvale, CA) at a wavelength of $450 \mathrm{~nm}$. We used commercial kits to determine concentrations of plasma fatty acids (Wako Chemicals USA Inc., Richmond, VA) and insulin (Coat-a-Count kit; Diagnostic Products Corp., Los Angeles, CA). We summarized these plasma metabolite data to obtain 1 value per cow per period before statistical analysis.

In addition to blood samples, we collected rumen fluid every $3 \mathrm{~h}$ over $24 \mathrm{~h}$ on d 21, starting at $0700 \mathrm{~h}$. Samples were collected from the cranial, ventral, and dorsal sacs, and then combined and strained through a perforated screen (Peetex, Sefar Canada Inc., Scarborough, ON, Canada). Samples were centrifuged at 3,000 $\times g$ at $4^{\circ} \mathrm{C}$ for $20 \mathrm{~min}$, and the supernatant was stored at $-20^{\circ} \mathrm{C}$ until further analysis. Rumen fluid samples were combined to form 1 sample per cow per period for analysis. The VFA profile was analyzed by gas chromatography as described by Khorasani et al. (1996) and rumen ammonia- $\mathrm{N}$ concentration was determined as described by Fawcett and Scott (1960) using a plate reader (SpectraMax 190).
All response variables were evaluated using the Fit Model procedure of JMP (version 11, SAS Institute Inc., Cary, NC). The model included the fixed effects of period, treatment, category, and interaction of category by treatment, as well as the random effect of cow nested within category. Treatment sequence, $3 \times$ to $1 \times$ vs. $1 \times$ to $3 \times$, had been included as a fixed effect in the initial statistical model; however, it was removed as its effect was not significant for all response variables. Significance was declared at $P \leq 0.05$ and tendency was declared at $0.05<P \leq 0.10$. Least squares means were separated using the Student $t$-test.

\section{RESULTS}

\section{Preliminary Studies}

In the group of 16 cows, 7 were higher-risk and 9 were lower-risk. The minimum and mean $\mathrm{pH}$ were lower $(P<$ 0.001; Table 3) for higher-risk cows than for lower-risk cows. We also observed a tendency $(P=0.08)$ for the maximum $\mathrm{pH}$ to be lower for higher-risk cows. The area below a pH of $5.8(P<0.001)$ and the acidosis index $(P<0.01)$ were both greater for higher-risk cows. We observed no differences in milk yield or DMI between higher-risk and lower-risk cows.

In time period 1 , the first $8 \mathrm{~h}$ after feeding, higher-risk cows ate for longer $(P=0.01$; Table 3$)$ than lower-risk cows; we observed no difference in ruminating time. We observed no difference in either eating or ruminating time in time period 2. In time period 3, higher-risk cows ate for less time $(P=0.01)$ and ruminated for longer $(P$ $=0.01)$ than lower-risk cows.

\section{Primary Experiment}

Feeding 3 times per day decreased $(P<0.01$; Table 4$)$ eating time between 0800 and 1500 and increased $(P<$ 0.01 ) eating time between 2200 and $0800 \mathrm{~h}$ for all cows, regardless of risk category, compared to $1 \times$ feeding. We also observed a treatment effect on ruminating while lying between 0800 and $1500 \mathrm{~h}$, in which cows fed $3 \times$ increased $(P<0.01)$ time ruminating while lying compared to cows fed $1 \times$. We observed an interaction effect $(P<0.01)$ for ruminating while standing between 2200 and $0800 \mathrm{~h}$, in which lower-risk cows decreased time ruminating while standing when fed $3 \times$. We observed no difference in behavior between 1500 and $2200 \mathrm{~h}$. We also observed no difference (Table 5) in treatment, category, or their interaction on sorting behavior.

With regards to rumen $\mathrm{pH}, 4$ cows were higher-risk and 4 were lower-risk, and within both groups 2 cows were late-lactation and 2 early-lactation. We observed a treatment $\times$ category interaction $(P=0.05)$ on area 
below a pH of $5.8(P=0.05$; Table 6$)$, in which $3 \times$ feeding reduced the area for higher-risk cows $(P<0.05)$ with no significant difference for lower-risk cows. We also observed an interaction $(P=0.03)$ effect on acidosis index, again in which higher-risk cows decreased $(P<0.05)$ their index when fed $3 \times$ with no significant difference for lower-risk cows. We observed no treatment or interaction between treatment and category on minimum $\mathrm{pH}$, but we did observe a tendency $(P=0.10)$ for higher-risk cows to have a lower nadir $\mathrm{pH}$ compared to lower-risk cows. Mean $\mathrm{pH}$ was lower $(P<0.05)$ for higher-risk than lower-risk cows, and we observed an interaction $(P<0.01)$ between treatment and category for maximum $\mathrm{pH}$, where higher-risk cows had a lower $(P<0.05)$ maximum $\mathrm{pH}$ when fed $3 \times$ than lower-risk cows. We observed no treatment or interaction between treatment and category effect on DMI, but higher-risk cows ate more than lower-risk cows ( 28.3 vs. $23.4 \mathrm{~kg} / \mathrm{d}$; $P=0.05)$. We observed no difference in total VFA or ammonia concentrations in rumen fluid between treatments or between risk categories for SARA (Table 7).

We observed no difference in plasma glucose or fatty acid concentrations; higher-risk cows tended $(P=0.06)$ to have a higher plasma insulin concentration than lower-risk cows, but this was not affected by treatment.

We observed no difference in milk yield (Table 8), but $3 \times$ feeding increased $(P=0.01)$ milk fat yield and tended $(P=0.06)$ to increase milk fat content compared to $1 \times$ feeding. We observed an interaction $(P=0.05)$ between treatment and category for milk $\mathrm{CP}$ yield, because responses to feeding frequency varied by risk group for SARA (Table 8). We observed no difference between category or treatment and MUN concentration.

\section{DISCUSSION}

The objective of the preliminary studies was to determine if there were any differences in feeding behavior between cows with a higher or lower risk of developing SARA. Our hypothesis was that higher-risk cows would eat for longer directly after feed delivery than lowerrisk cows, and we found that cows at higher risk for SARA did eat for longer in the $8 \mathrm{~h}$ after feeding and for less time in the $8 \mathrm{~h}$ before feed delivery on the next day than lower-risk cows. We observed no difference in total DMI between risk categories, so the differences in eating time distribution were likely the contributing factor to certain cows' development of SARA, even though all cows were fed the same diet. The amount of VFA produced in a period of time depends on meal size and eating rate, in which a large intake of fermentable carbohydrates increases the risk for SARA (Owens et al., 1998; González et al., 2012). From the results of the preliminary studies, we evaluated a possible management approach that would encourage higher-risk cows to eat less after feed delivery and distribute their eating time more evenly throughout the day. The hypothesis was that frequent feeding $(3 \times$ vs. $1 \times)$ would increase the distribution of eating and reduce the severity of SARA experienced by higher-risk cows. Some nutritional approaches to mitigating SARA, such as feeding

Table 3. Comparison of milk yield, DMI, rumen $\mathrm{pH}$, and behavior measurements between SARA risk categories in the preliminary studies

\begin{tabular}{|c|c|c|c|c|c|}
\hline Variable $^{1}$ & $\begin{array}{l}\text { Higher } \\
\text { risk }^{2}\end{array}$ & SE & $\begin{array}{c}\text { Lower } \\
\text { risk }^{2}\end{array}$ & $\mathrm{SE}$ & $P$-value \\
\hline Milk yield, $\mathrm{kg} / \mathrm{d}$ & 25.2 & 2.75 & 29.9 & 2.43 & 0.23 \\
\hline $3.5 \% \mathrm{FCM}^{3}$ & 23.7 & 3.85 & 28.9 & 3.27 & 0.12 \\
\hline DMI, kg/d & 21.1 & 1.30 & 20.0 & 1.48 & 0.59 \\
\hline \multicolumn{6}{|l|}{ Ruminal pH } \\
\hline Nadir & 5.20 & 0.08 & 5.70 & 0.07 & $<0.001$ \\
\hline Mean & 5.96 & 0.06 & 6.40 & 0.05 & $<0.001$ \\
\hline Maximum & 6.70 & 0.06 & 6.90 & 0.05 & 0.08 \\
\hline Duration $\mathrm{pH}<5.8, \min / \mathrm{d}$ & 535 & 60.4 & 18.4 & 53.2 & $<0.001$ \\
\hline Area $\mathrm{pH}<5.8, \mathrm{pH} \times \min / \mathrm{d}$ & 148 & 24.1 & 2.20 & 21.3 & $<0.001$ \\
\hline Acidosis index, $\mathrm{pH} \times \min / \mathrm{kg}$ & 8.03 & 1.55 & 0.11 & 1.37 & $<0.01$ \\
\hline \multicolumn{6}{|l|}{ Eating, min } \\
\hline Time period 1 & 186 & 7.94 & 153 & 7.20 & 0.01 \\
\hline Time period 2 & 62.1 & 10.1 & 63.3 & 9.16 & 0.78 \\
\hline Time period 3 & 19.3 & 5.95 & 42.8 & 5.40 & 0.01 \\
\hline \multicolumn{6}{|l|}{ Ruminating, min } \\
\hline Time period 1 & 129 & 11.9 & 151 & 10.5 & 0.20 \\
\hline Time period 2 & 200 & 17.2 & 178 & 15.2 & 0.36 \\
\hline Time period 3 & 243 & 12.0 & 197 & 10.6 & 0.01 \\
\hline
\end{tabular}

${ }^{1}$ Each variable was measured in 3 separate 8 -h time periods, starting with the hour the cow was fed.

${ }^{2}$ Cows were categorized as higher risk or lower risk for developing SARA using a threshold of 1.0 in acidosis index (area below pH 5.8/DMI).

${ }^{3} \mathrm{FCM}=[0.4324 \times$ milk yield $(\mathrm{kg})]+[16.126 \times$ fat yield $(\mathrm{kg})]($ Tyrrell and Reid, 1965). 
Table 4. Effect of feeding frequency and risk category on feeding and lying behavior in the primary experiment

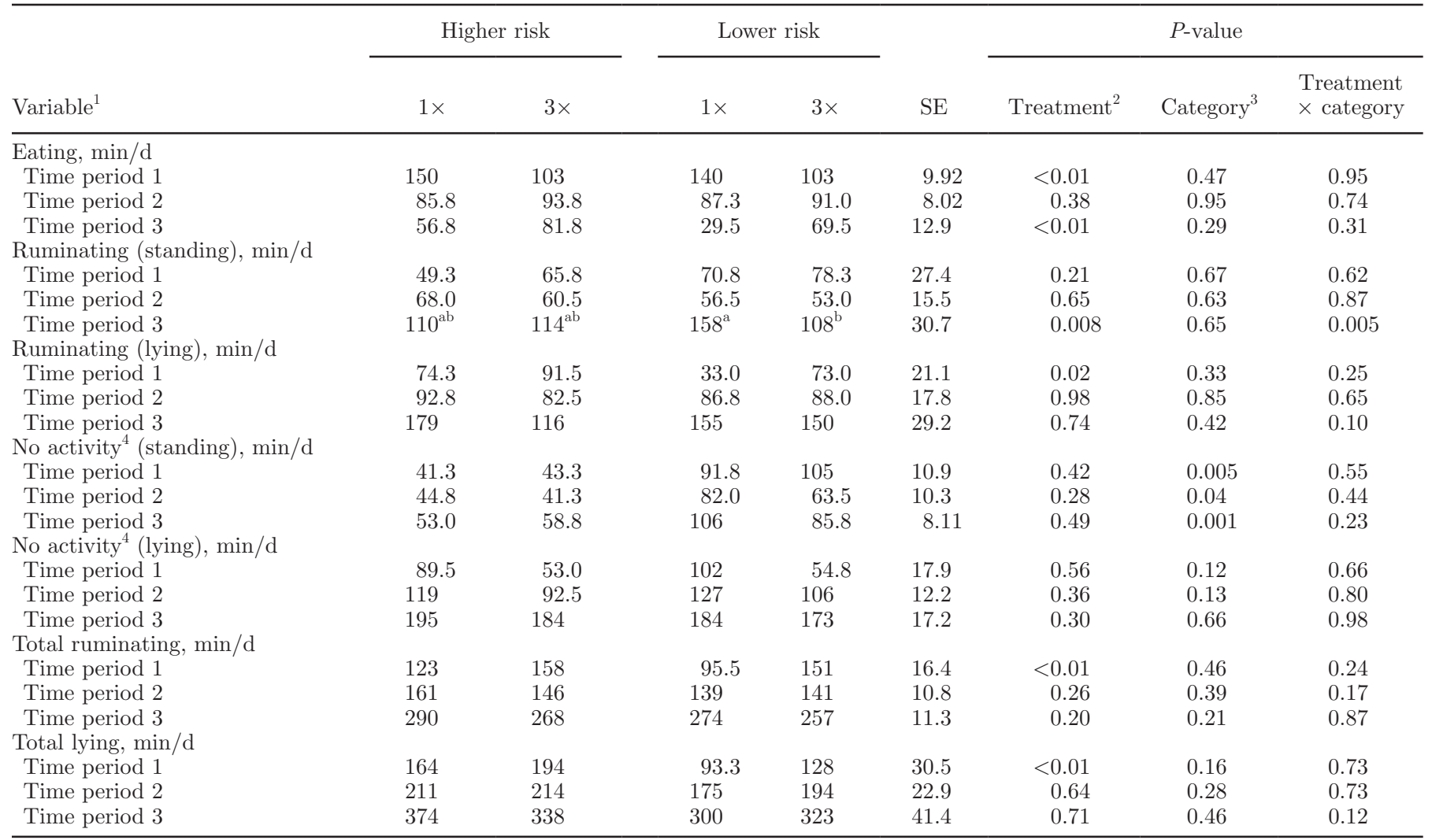

$\overline{\mathrm{a}, \mathrm{b}}$ Means within each row with different superscripts were significantly different from each other $(P \leq 0.05)$.

${ }^{1}$ Each variable was measured in 3 separate periods: 0800 to $1500 \mathrm{~h}$ (time period 1), 1500 to $2200 \mathrm{~h}$ (time period 2), and 2200 to $0800 \mathrm{~h}$ (time period 3).

${ }^{2}$ Feeding frequency treatment was once per day $(1 \times ; 0800 \mathrm{~h})$ or 3 times per day $(3 \times ; 0800,1500$, and $2200 \mathrm{~h})$.

${ }^{3}$ Cows were categorized as higher risk or lower risk for developing SARA using a threshold of 1.0 in acidosis index (area below pH 5.8/DMI).

${ }^{4}$ No activity represented the absence of eating and ruminating behaviors.

a lower-grain diet, would improve the rumen health of higher-risk cows, but would also likely reduce milk production in lower-risk cows that did not experience SARA. In the primary experiment, we evaluated feeding frequency $(3 \times$ vs. $1 \times)$ as a management approach to reduce the severity of SARA in higher-risk cows without decreasing the productivity of lower-risk cows.
In previous experiments, increased feeding frequency has had a variable effect on rumen $\mathrm{pH}$. Shabi et al. (1999) found a decrease in mean rumen $\mathrm{pH}$ when cows were fed 4 times versus 2 times per day, but cows fed 4 times per day had increased total DMI and NSC intake. Several experiments have found no effect of frequent feeding on mean rumen $\mathrm{pH}$, but they did observe a

Table 5. Effect of feeding frequency and risk category on sorting in the primary experiment

\begin{tabular}{|c|c|c|c|c|c|c|c|c|}
\hline \multirow[b]{2}{*}{ Sorting index ${ }^{1}$} & \multicolumn{2}{|c|}{ Higher risk } & \multicolumn{2}{|c|}{ Lower risk } & \multirow[b]{2}{*}{$\mathrm{SE}$} & \multicolumn{3}{|c|}{$P$-value } \\
\hline & $1 \times$ & $3 \times$ & $1 \times$ & $3 \times$ & & Treatment $^{2}$ & Category $^{3}$ & Treatment $\times$ category \\
\hline$>19.0 \mathrm{~mm}$ & 93.1 & 96.9 & 95.7 & 94.5 & 3.85 & 0.47 & 0.98 & 0.22 \\
\hline 19.0 to $8.0 \mathrm{~mm}$ & 99.7 & 99.7 & 99.7 & 99.4 & 0.42 & 0.61 & 0.72 & 0.76 \\
\hline 8.0 to $1.18 \mathrm{~mm}$ & 100.7 & 100.4 & 100.6 & 101.7 & 0.69 & 0.43 & 0.50 & 0.21 \\
\hline$<1.18 \mathrm{~mm}$ & 101.8 & 101.3 & 101.0 & 103.0 & 1.03 & 0.31 & 0.73 & 0.11 \\
\hline
\end{tabular}

${ }^{1}$ Sorting index was calculated as the ratio of actual intake to predicted intake for particles retained on each sieve of the separator. A sorting index above 100 indicated sorting for particles and an index below 100 indicated sorting against particles (Leonardi and Armentano, 2003).

${ }^{2}$ Feeding frequency treatment was once per day $(1 \times ; 0800 \mathrm{~h})$ or 3 times per day $(3 \times ; 0800,1500$, and $2200 \mathrm{~h})$.

${ }^{3}$ Cows were categorized as higher risk or lower risk for developing SARA using a threshold of 1.0 in acidosis index (area below pH $5.8 / \mathrm{DMI}$ ). 
Table 6. Effect of feeding frequency and risk category on rumen $\mathrm{pH}$ measurements in the primary experiment

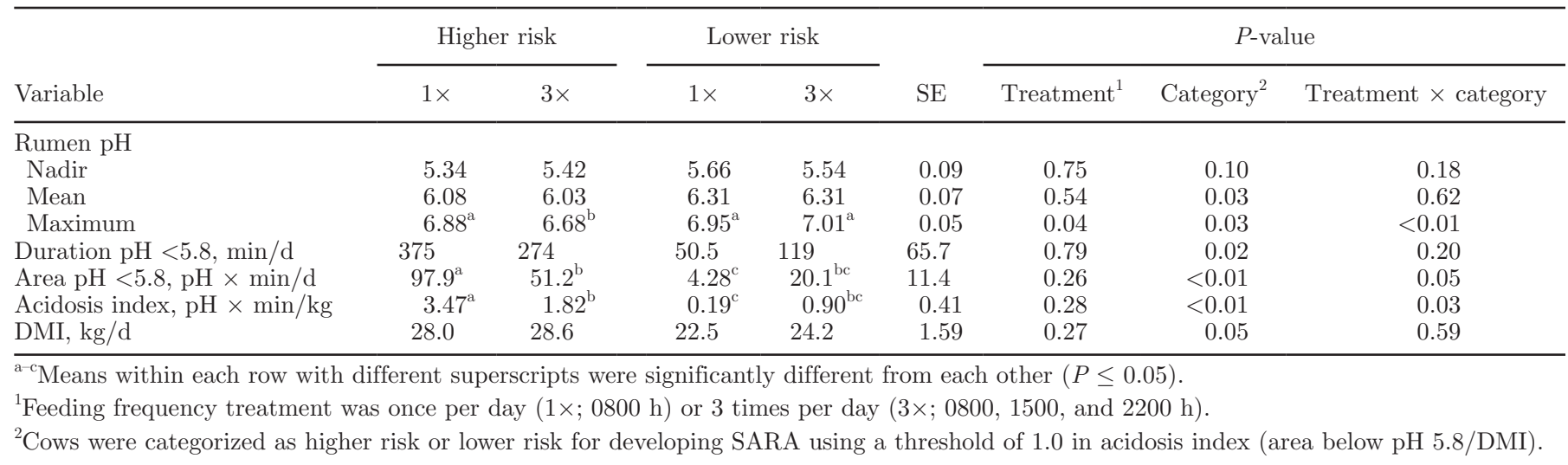

decrease in the diurnal variation of $\mathrm{pH}$; feeding more often maintained a more stable $\mathrm{pH}$ throughout the day (Kaufmann, 1976; Bragg et al., 1986; French and Kennelly, 1990). Robinson and McQueen (1994) reported an increase in mean rumen $\mathrm{pH}$ when cows were fed 5 times versus 2 times per day, a finding that they attributed to the dramatic decrease in rumen $\mathrm{pH}$ following each of the twice-daily feedings. In the present experiment, we observed no main effect of feeding frequency on rumen $\mathrm{pH}$ parameters, except for maximum rumen fluid $\mathrm{pH}$. Nevertheless, once cows were categorized as higher-risk or lower-risk for SARA, then feeding 3 times per day reduced rumen $\mathrm{pH}$ differently for each category. Feeding more often reduced the severity of SARA for higher-risk cows based on area of rumen fluid $\mathrm{pH}$ below 5.8 , and had no effect on lower-risk cows.

The positive effects of frequent feeding on rumen $\mathrm{pH}$ can likely be attributed to a change in feeding behavior, specifically eating pattern. When cows were fed more often, regardless of SARA risk category, we observed a more even distribution of eating over the 3 time periods. Mäntysaari et al. (2006) found a similar result when feeding cows 5 times per day versus once per day; frequent feeding resulted in more even eating distribution throughout the day. When DeVries et al. (2005) fed cows 4 times per day versus twice per day, they found that cows fed more often ate more in the late evening and early morning (2000 to $0600 \mathrm{~h}$ ) and ate less in the $90 \mathrm{~min}$ after feeding. The delivery of fresh feed stimulates cattle to eat (DeVries and von Keyserlingk, 2005) and likely contributes to the even consumption of feed throughout the day. As mentioned earlier, larger meals in a shorter amount of time can increase VFA production and raise the risk for SARA (González et al., 2012). Serment and Giger-Reverdin (2012) observed a steeper decrease in the rumen $\mathrm{pH}$ of goats classified as "fast eaters," where $70 \%$ of the daily feed was consumed in the 90 min after feeding. In the present study, data need to be interpreted with caution, because DMI was measured daily but not for each time

Table 7. Effects of feeding frequencies and risk categories on total VFA, VFA composition, rumen ammonia, and blood plasma metabolites and hormones in the primary experiment

\begin{tabular}{|c|c|c|c|c|c|c|c|c|}
\hline Variable & \multicolumn{2}{|c|}{ Higher risk } & \multicolumn{2}{|c|}{ Lower risk } & $\mathrm{SE}$ & \multicolumn{3}{|c|}{$P$-value } \\
\hline Acetic & 56.1 & 55.1 & 57.7 & 57.4 & 1.84 & 0.41 & 0.46 & 0.65 \\
\hline Propionic & 24.3 & 25.8 & 23.1 & 23.8 & 2.31 & 0.13 & 0.63 & 0.50 \\
\hline Isobutyric & 1.13 & 1.04 & 1.13 & 1.12 & 0.05 & 0.33 & 0.43 & 0.46 \\
\hline Butyric & 14.0 & 13.8 & 13.7 & 13.8 & 1.26 & 0.93 & 0.95 & 0.89 \\
\hline Caproic & 0.54 & 0.60 & 0.47 & 0.40 & 0.04 & 0.92 & 0.02 & 0.21 \\
\hline Total VFA, $\mathrm{m} M$ & 107 & 114 & 103 & 102 & 6.69 & 0.56 & 0.36 & 0.36 \\
\hline Rumen $\mathrm{NH}_{3}, \mathrm{mg} / \mathrm{dL}$ & 9.24 & 8.12 & 6.24 & 5.91 & 1.52 & 0.60 & 0.18 & 0.77 \\
\hline Plasma glucose, $\mathrm{mg} / \mathrm{dL}$ & 61.7 & 63.4 & 63.2 & 63.7 & 1.73 & 0.34 & 0.69 & 0.58 \\
\hline Plasma fatty acids, $\mathrm{mEq} / \mathrm{L}$ & 150 & 92.9 & 131 & 121 & 30.3 & 0.23 & 0.90 & 0.37 \\
\hline Plasma insulin, $\mu \mathrm{IU} / \mathrm{mL}$ & 8.51 & 8.25 & 4.31 & 4.54 & 1.23 & 0.98 & 0.06 & 0.61 \\
\hline
\end{tabular}

${ }^{1}$ Feeding frequency treatment was once per day $(1 \times ; 0800 \mathrm{~h})$ or 3 times per day $(3 \times ; 0800,1500$, and $2200 \mathrm{~h})$.

${ }^{2}$ Cows were categorized as higher risk or lower risk for developing SARA using a threshold of 1.0 in acidosis index (area below pH 5.8/DMI). 
Table 8. Effect of feeding frequency and risk category on milk yield and milk components in the primary experiment

\begin{tabular}{|c|c|c|c|c|c|c|c|c|}
\hline Variable & \multicolumn{2}{|c|}{ Higher risk } & \multicolumn{2}{|c|}{ Lower risk } & SE & \multicolumn{3}{|c|}{$P$-value } \\
\hline \multicolumn{9}{|l|}{ Yield, kg/d } \\
\hline Fat & 1.12 & 1.25 & 1.04 & 1.19 & 0.18 & 0.01 & 0.79 & 0.85 \\
\hline $\mathrm{CP}$ & 1.26 & 1.21 & 1.19 & 1.23 & 0.25 & 0.74 & 0.95 & 0.05 \\
\hline Lactose & 1.76 & 1.83 & 1.70 & 1.85 & 0.50 & 0.35 & 0.88 & 0.09 \\
\hline $\mathrm{CP}, \%$ & 3.52 & 3.37 & 3.20 & 3.27 & 0.26 & 0.56 & 0.58 & 0.20 \\
\hline Lactose, \% & 4.57 & 4.40 & 4.54 & 4.60 & 0.13 & 0.51 & 0.60 & 0.21 \\
\hline MUN, mg/dL & 12.2 & 12.3 & 11.5 & 11.4 & 1.22 & 0.97 & 0.65 & 0.90 \\
\hline
\end{tabular}

${ }^{1}$ Feeding frequency treatment was once per day $(1 \times ; 0800 \mathrm{~h})$ or 3 times per day $(3 \times ; 0800,1500$, and $2200 \mathrm{~h})$.

${ }^{2}$ Cows were categorized as higher risk or lower risk for developing SARA using a threshold of 1.0 in acidosis index (area below pH 5.8/DMI).

${ }^{3} \mathrm{FCM}=[0.4324 \times$ milk yield $(\mathrm{kg})]+[16.126 \times$ fat yield $(\mathrm{kg})]($ Tyrrell and Reid, 1965).

period. We assumed that a difference in the distribution of eating time led to a similar difference in the distribution of intake, and considered it as a possible reason for variable rumen $\mathrm{pH}$ among animals fed the same diet, but this still needs to be confirmed. Daily eating time and overall DMI are not strongly correlated (Dado and Allen, 1994), so it is also possible that distribution of eating time affected ruminal fermentation directly, without changes in distribution of DMI.

In addition to eating pattern, we looked at other behaviors as potential contributing factors to the reduced severity of SARA. Feeding $3 \times$ increased time spent ruminating while lying during time period 1 (0800 to $1500 \mathrm{~h}$ ) compared to feeding $1 \times$, which was associated with the decrease in time spent eating. This could be another possible causal factor, because increased time spent ruminating has been shown to increase rumen $\mathrm{pH}$ (Beauchemin et al., 2003).

Overall DMI did not differ between feeding frequency treatments, and this has also been observed in previous work (Klusmeyer et al., 1990; DeVries et al., 2005). Shabi et al. (1999) found an increase in DMI when feeding more often, but feed was available for an extra $2 \mathrm{~h}$ per day for cows fed 4 times per day versus twice per day. In the present study, animal responses to $3 \times$ feeding in rumen $\mathrm{pH}$ could not be attributed to daily DMI. However, higher-risk cows had greater DMI by 5 $\mathrm{kg} / \mathrm{d}$ than lower-risk cows. Although increased DMI of a highly fermentable diet increases the risk for SARA (Owens et al., 1998), we did not observe increased DMI for higher-risk cows in the preliminary studies or in past experiments (Gao and Oba, 2014, 2015). Therefore, we cannot conclude that DMI is always greater in higher-risk cows.

Sorting against long particles in the TMR can reduce NDF intake (Leonardi at al., 2005) and increase risk for SARA (Cook et al., 2004). However, frequent feeding did not affect sorting behavior in the present study, so reduced severity of SARA in the higher-risk cows could not be attributed to reduced sorting. Hart et al. (2014) had similar findings when cows were fed 3 times per day, observing no change in sorting behavior. However, DeVries et al. (2005) evaluated the effect of feeding frequency 1,2 , or 4 times per day on the NDF content of the diet over time as a measure of feed sorting, and reported an interaction between treatment and sampling time, indicating that cows fed once per day sorted more than those fed twice per day. Sova et al. (2013) also observed that group-housed cows on 24 different commercial dairies sorted less against long particles when they were fed twice per day instead of once per day. Endres and Espejo (2010) sampled TMR from 50 different freestall barns and found a negative relationship between feeding frequency and change in NDF content of the TMR throughout the day, where feeding once per day resulted in a greater change in the NDF content of the TMR. The differences in experimental design between these studies and the present study (number of cows, group vs. individual sampling, and diet composition) may explain the discrepancies in effects of frequent feeding on sorting behavior.

In addition to the positive effects of $3 \times$ feeding on the severity of SARA in higher-risk cows, we found positive effects on milk fat in all cows. Feeding cows 3 times per day did not increase milk yield, consistent with previous work (Shabi et al., 1999; Mäntysaari et al., 2006; Hart et al., 2014). However, it did increase milk fat yield and tended to increase milk fat concentration compared to $1 \times$ feeding. Effects of frequent feeding on milk component production have been variable, with some studies reporting increases in milk fat yield and concentration (Sutton et al., 1988; French and Ken- 
nelly, 1990; Shabi et al., 1999) and others reporting no effect (Klusmeyer et al., 1990; Mäntysaari et al., 2006; Hart et al., 2014). These discrepancies may be attributable to dietary forage content; the studies that reported greater milk fat yield for cows fed more frequently, including the present study, fed low-forage diets, with 10 to $48.8 \%$ of the diet DM as forage, whereas studies that did not report an effect of increased feeding frequency fed cows diets with greater forage content, 49 to $55 \%$ of the diet DM. Providing low-forage diets may have resulted in a lower rumen $\mathrm{pH}$, leading to a greater benefit from more frequent feeding. However, the current study reported greater milk fat yield for the $3 \times$ treatment for all cows, with no significant change in the severity of SARA for lower-risk cows. These results indicate that rumen $\mathrm{pH}$ is likely not the sole reason why milk fat yield was elevated in cows fed more often. Oetzel (2007) suggested that the milk fat depression seen with SARA might be influenced by factors other than rumen $\mathrm{pH}$. For example, large amounts of polyunsaturated fatty acids in the diet can contribute to incomplete biohydrogenation of fatty acids in the rumen and milk fat depression (Bauman and Griinari, 2003). In the present experiment, we fed vegetable oil at $1 \%$ DM, which may have overwhelmed the rumen microbes' capability to complete biohydrogenation when fed $1 \times$ rather than $3 \times$, resulting in milk fat depression. However, neither milk fatty acid composition nor microbial profile was measured in the current experiment; these could have given some insight into the causal factors behind the milk fat increase when cows were fed $3 \times$.

In the present study, we observed no effect of treatment on total rumen fluid VFA concentration or molar proportions of VFA, so changes in VFA did not contribute to the treatment effect on milk fat yield. Previous studies have reported variable results for the effect of feeding frequency on rumen VFA parameters. French and Kennelly (1990) also reported no change in total VFA concentrations or molar proportions when cows were fed a concentrate 2 or 12 times per day or a TMR 12 times per day. Two experiments observed no change in the total concentration of VFA, but a tendency for increase in the molar proportion of propionate with more frequent feeding (Klusmeyer et al., 1990; Shabi et al., 1999), whereas Robinson and McQueen (1994) found a decrease in total VFA concentration when cows were fed 5 times per day compared with twice per day, but noted a decrease in propionate concentration. Bragg et al. (1986) reported no change in total VFA concentration but found an increase in the molar proportion of acetate when cows were fed 8 times per day versus twice per day. All of these studies had drastically different treatments, diets, and feeding frequencies, and these differences may have contributed to the variable results. We collected rumen fluid samples every $3 \mathrm{~h}$ in the present study, but studies with at least hourly sampling did not show treatment effects on VFA concentration and its profile (Sutton et al., 1988; French and Kennelly, 1990). As such, the lack of treatment effects in the present experiment cannot necessarily be attributed to insufficient sampling frequency. We observed no difference in total VFA concentrations between higher-risk and lower-risk cows, a finding also reported by Gao and Oba (2014). Chen et al. (2012) reported an increase in total VFA concentration in higher-risk steers as well as increased rumen bacterial density, indicating an increase in VFA production. In the second paper from that experiment, Schlau et al. (2012) found increased expression of genes involved in VFA absorption for lower-risk steers, and this may have contributed to the decreased total VFA concentration. The use of beef steers and a larger amount of concentrate in the diet (95\%) may explain the discrepancies between these experiments and the present study.

Increasing feeding frequency did not affect the concentrations of glucose, insulin, or fatty acids in the plasma of dairy cows. Previous studies (French et al., 1990; Rooke et al., 2008) have also reported that the average daily concentrations of these metabolites were not affected by feeding frequency. A couple of studies did report a tendency for increased feeding frequency to lower peak and average insulin concentrations (Sutton et al., 1988; French and Kennelly, 1990), but these studies fed cows 8 or 12 times a day, and that may have contributed to the discrepancies with the current study. Nonetheless, the plasma metabolites measured did not explain the treatment effects in this experiment.

\section{CONCLUSIONS}

The current study showed that cows at higher risk of developing SARA ate for longer after feeding compared with those at lower risk. Feeding 3 times per day, which decreased the duration of eating after the first feeding and increased eating time in the later hours of the day, reduced the severity of SARA experienced by higherrisk cows without negatively affecting the productivity of lower-risk cows. Increasing feeding frequency also resulted in greater milk fat yield, regardless of risk category. Frequent feeding, particularly for high-grain diets, may be a beneficial approach for reducing SARA and improving production in lactating dairy cows.

\section{ACKNOWLEDGMENTS}

These studies were supported by Alberta Milk (Edmonton, AB, Canada) and Natural Sciences and Engineering Research Council of Canada (Ottawa, ON, 
Canada). The authors thank A. Ruiz-Sanchez, Y. Sun, D. Larsen, S. Espinoza, and J. Haisan (University of Alberta, Edmonton, AB, Canada) for their assistance with animal handling and sample collection.

\section{REFERENCES}

AOAC International. 2002. Official Methods of Analysis. 17th ed. AOAC Int., Gaithersburg, MD.

Bauman, D. E., and J. M. Griinari. 2003. Nutritional regulation of milk fat synthesis. Annu. Rev. Nutr. 23:203-227.

Beauchemin, K. A., W. Z. Yang, and L. M. Rode. 2003. Effects of particle size of alfalfa-based dairy cow diets on chewing activity, ruminal fermentation, and milk production. J. Dairy Sci. 86:630-643.

Bragg, D. St. A., M. R. Murphy, and C. L. Davis. 1986. Effect of source of carbohydrate and frequency of feeding on rumen parameters in dairy steers. J. Dairy Sci. 69:392-402.

Canadian Council on Animal Care. 2009. CCAC guidelines on: The care and use of farm animals in research, teaching and testing. CCAC, Ottawa, ON, Canada.

Chen, Y., M. Oba, and L. L. Guan. 2012. Variation of bacterial communities and expression of the toll-like receptor genes in the rumen of steers differing in susceptibility to subacute ruminal acidosis. Vet. Microbiol. 159:451-459.

Cook, N. B., K. V. Nordlund, and G. R. Oetzel. 2004. Environmental influences on claw horn lesions associated with laminitis and subacute ruminal acidosis in dairy cows. J. Dairy Sci. 87:E36-E46.

Dado, R. G., and M. S. Allen. 1993. Continuous computer acquisition of feed and water intakes, chewing, reticular motility, and ruminal pH of cattle. J. Dairy Sci. 76:1589-1600.

Dado, R. G., and M. S. Allen. 1994. Variation in and relationships among feeding, chewing, and drinking variables for lactating dairy cows. J. Dairy Sci. 77:132-144.

DeVries, T. J., and M. A. G. von Keyserlingk. 2005. Time of feed delivery affects the feeding and lying patterns of dairy cows. J. Dairy Sci. 88:625-631.

DeVries, T. J., M. A. G. von Keyserlingk, and K. A. Beauchemin. 2005. Frequency of feed delivery affects the behavior of lactating dairy cows. J. Dairy Sci. 88:3553-3562.

Endres, M. I., and L. A. Espejo. 2010. Feeding management and characteristics of rations for high-producing dairy cows in freestall herds. J. Dairy Sci. 93:822-829.

Fawcett, J. K., and J. E. Scott. 1960. A rapid and precise method for the determination of urea. J. Clin. Pathol. 13:156-159.

French, N., G. De Boer, and J. J. Kennelly. 1990. Effects of feeding frequency and exogenous somatotropin on lipolysis, hormone profiles, and milk production in dairy cows. J. Dairy Sci. 73:1552-1559.

French, N., and J. J. Kennelly. 1990. Effects of feeding frequency on ruminal parameters, plasma insulin, milk yield, and milk composition in Holstein cows. J. Dairy Sci. 73:1857-1863.

Gao, X., and M. Oba. 2014. Relationship of severity of subacute ruminal acidosis to rumen fermentation, chewing activities, sorting behaviour, and milk production in lactating dairy cows fed a highgrain diet. J. Dairy Sci. 97:3006-3016.

Gao, X., and M. Oba. 2015. Characteristics of dairy cows with a greater of lower risk of subacute rumen acidosis: volatile fatty acid absorption, rumen digestion kinetics and consistency of the risk. J. Dairy Sci. 98(Suppl. 2):388. (Abstr.)

González, L. A., X. Manteca, S. Calsamiglia, K. S. SchwartzkopfGenswein, and A. Ferret. 2012. Ruminal acidosis in feedlot cattle: Interplay between feed ingredients, rumen function and feeding behavior (a review). Anim. Feed Sci. Technol. 172:66-79.

Hart, K. D., B. W. McBride, T. F. Duffield, and T. J. DeVries. 2014. Effect of frequency of feed delivery on the behavior and productivity of lactating dairy cows. J. Dairy Sci. 97:1713-1724.
Kaufmann, W. 1976. Influence of the composition of the ration and the feeding frequency on $\mathrm{pH}$ regulation in the rumen and on feed intake in ruminants. Livest. Prod. Sci. 3:103-114.

Khorasani, G. R., E. K. Okine, and J. J. Kennelly. 1996. Forage source alters nutrient supply to the intestine without influencing milk yield. J. Dairy Sci. 79:862-872.

Klusmeyer, T. H., M. R. Cameron, G. C. McCoy, and J. H. Clark. 1990. Effects of feed processing and frequency of feeding on ruminal fermentation, milk production, and milk composition. J. Dairy Sci. 73:3538-3543.

Leonardi, C., and L. E. Armentano. 2003. Effect of quantity, quality, and length of alfalfa hay on selective consumption by dairy cows. J. Dairy Sci. 86:557-564.

Leonardi, C., K. J. Shinners, and L. E. Armentano. 2005. Effect of different dietary geometric mean particle length and particle size distribution of oat silage on feeding behavior and productive performance of dairy cattle. J. Dairy Sci. 88:698-710.

Mäntysaari, P., H. Khalili, and J. Sariola. 2006. Effect of feeding frequency of a total mixed ration on the performance of high-yielding dairy cows. J. Dairy Sci. 89:4312-4320.

Nocek, J. E. 1997. Bovine acidosis: Implications on laminitis. J. Dairy Sci. 80:1005-1028.

Oetzel, G. R. 2007. Subacute ruminal acidosis in dairy herds: Physiology, pathophysiology, milk fat responses, and nutritional management. Preconvention Seminar 7A. Am. Assoc. Bovine Pract. 40th Annu. Conf.

Owens, F. N., D. S. Secrist, W. J. Hill, and D. R. Gill. 1998. Acidosis in cattle: A review. J. Anim. Sci. 76:275-286.

Penner, G. B., J. R. Aschenbach, G. Gabel, R. Rackwitz, and M. Oba 2009. Epithelial capacity for apical uptake of short chain fatty acids is a key determinant for intraruminal $\mathrm{pH}$ and the susceptibility to subacute ruminal acidosis in sheep. J. Nutr. 139:1714-1720.

Penner, G. B., K. A. Beauchemin, and T. Mutsvangwa. 2006. An evaluation of the accuracy and precision of a stand-alone submersible continuous ruminal $\mathrm{pH}$ measurement system. J. Dairy Sci. 89:2132-2140.

Penner, G. B., K. A. Beauchemin, and T. Mutsvangwa. 2007. Severity of ruminal acidosis in primiparous Holstein cows during the periparturient period. J. Dairy Sci. 90:365-375.

Robinson, P. H., and R. E. McQueen. 1994. Influence of supplemental protein and feeding frequency on rumen fermentation and performance in dairy cows. J. Dairy Sci. 77:1340-1353.

Rooke, J. A., A. Ainslie, R. G. Watt, F. M. Alink, T. G. McEvoy, K. D. Sinclair, P. C. Garnsworthy, and R. Webb. 2008. Feeding frequency has diet-dependent effects on plasma hormone concentrations but does not affect oocyte quality in dairy heifers fed fibre- or starch-based diets. Animal 2:1361-1370.

Schlau, N., L. L. Guan, and M. Oba. 2012. The relationship between rumen acidosis resistance and expression of genes involved in regulation of intracellular $\mathrm{pH}$ and butyrate metabolism of ruminal epithelial cells in steers. J. Dairy Sci. 95:5866-5875.

Serment, A., and S. Giger-Reverdin. 2012. Effect of the percentage of concentrate on intake pattern in mid-lactation goats. Appl. Anim. Behav. Sci. 141:130-138.

Shabi, Z., I. Bruckental, S. Zamwell, H. Tagari, and A. Arieli. 1999. Effects of extrusion of grain and feeding frequency on rumen fermentation, nutrient digestibility, and milk yield and composition in dairy cows. J. Dairy Sci. 82:1252-1260.

Sova, A. D., S. J. LeBlanc, B. W. McBride, and T. J. DeVries. 2013. Associations between herd-level feeding management practices, feed sorting, and milk production in freestall dairy farms. J. Dairy Sci. 96:4759-4770.

Sutton, J. D., I. C. Hart, S. V. Morant, E. Schuller, and A. D. Simmonds. 1988. Feeding frequency for lactating cows: Diurnal patterns of hormones and metabolites in peripheral blood in relation to milk-fat concentration. Br. J. Nutr. 60:265-274.

Tyrrell, H. F., and J. T. Reid. 1965. Prediction of the energy of cow's milk. J. Dairy Sci. 48:1215-1223. 